\title{
Design and Implementation of Rural Electrification Framework using Photovoltaic
}

\author{
N. Rishikesh, N. P. Gopika
}

\begin{abstract}
The need to electrify all rural areas in India is quite compelling. However, the focus has now shifted from traditional fuel-based systems to generate electricity to renewable sources for energy generation. Though there are subsidies and policies that encourage the use of solar Photovoltaic (PV) systems, there is a need for an appropriate framework. This framework could not only offer substantial directions but it would also act as grounds to enhance rural electrification in India using solar PVs. From this perspective, the current research attempts to structure an innovative framework for solar PV system that could facilitate rural electrification in India. In particular, the district of Damoh in Madhya Pradesh was chosen as there are many villages without electricity in this district. PVsyst software was utilized to simulate the outcomes that included mathematical models and diverse components based on $\mathrm{PV}$, for simulation. Three designs were developed to facilitate the simulation. These included; PVs linked with microgrid devoid of battery, individual PV systems without microgrid link and solar PVs linked to microgrid with battey. The framework for rural electrification using solar PVs will offer policy makers with insights with regards to implementing $P V$ systems. It will also offer inputs as to the feasibility of implementing a specific system on several parameters. These would comprise of; number of households within a village, detached households etc. Nonetheless, research in future is also warranted to explore the scope for other sources of renewable energy.
\end{abstract}

Keywords : Rural electrification, electrification framework, solar PV, solar irradiation, micro grid

\section{INTRODUCTION}

$W_{\text {ith the use of energy sources that are renewable, it is }}$ possible to restrict or at least slowdown the rate of global warming. Of late, photovoltaic systems have assumed much significance owing to the multiple advantages it offers in terms of conserving natural resources [1]. It has also emerged that energy sources that are based on fossil fuels will eventually deplete over the course of time as they are limited. Subsequently, they immensely contribute to climate change at a global level [2]. In order to safeguard the environment and also with the intention of increasing access to electricity for people living in remote areas, alternative energy sources like

Revised Manuscript Received on May 25, 2020.

* Correspondence Author

N. Rishikesh*, Assistant professor of Electrical and Electronics Engineering at Bannari Amman Institute of Technology, Erode.

N. P. Gopika, Department Assistant professor of Electrical and Electronics Engineering at Bannari Amman Institute of Technology, Erode

(C) The Authors. Published by Blue Eyes Intelligence Engineering and Sciences Publication (BEIESP). This is an open access article under the CC BY-NC-ND license (http://creativecommons.org/licenses/by-nc-nd/4.0/) solar energy imbibed by photovoltaic systems can be of much significance [3]. The power sector in India has been grappling with several diverse challenges that arise from the much known divide between the rural and urban in the nation. The most prominent amongst such challenges happen to be the vast gap between demand and supply. The Indian census data [4] of 2011 revealed that out of the total population within the nation around 69 per cent happen to be rural while around 68 per cent of all households are located in rural regions [5]. The crisis of energy within India is underlined by the fact that a large portion of the population in the rural areas in India is poor in terms of energy. Poverty in energy which is signified with a lack of access to contemporary energy services results from poverty in terms of income. The poverty stricken people in rural areas are not in a position to afford the costs involved in acquiring energy services. They also happen to reside in dwellings that are sub-standard which cannot be linked with contemporary energy systems [6]. To satiate the energy requirements and the necessity to provide electricity within rural areas in India, the focus shifted from traditional generation of fuel based energy t to energy sources that were renewable. From this perspective, generation of solar energy plays a significant role as the sun happens to be a source of abundant energy. Energy that is generated by the sun is usually unused and by harnessing this energy it can prove to be the answer for mitigating the use of fossil fuels [7]. It is possible to harness the potential of solar energy with the help of solar photovoltaic systems. This technology has gained much prominence as compared to energy generation from wind power plants that are associated with ample solar irradiation that takes place the year around, and substantially reduces the cost of PV panels [8]. Nonetheless, designing and implementing solar power systems across rural regions in India that are yet to be electrified is confronted with many challenges.

\section{LITERATURE REVIEW}

\section{A. Solar Thermoelectricity}

According to Fan [9] laboratories conducted tests for a particular thermoelectric generator in experimental conditions which were managed. Within the laboratory, solar thermoelectricity as a concept happens to be quite novel. However, there has not been much development in this area that would satiate the market needs. Nonetheless, it is projected that solar thermoelectricity would capture a substantial market share in future. It is also possible to merge a thermoelectric generator along with diverse systems, by utilizing solar energy on account of its special nature and heat energy of low-grade. Therefore, an overall higher rate of final efficiency can be achieved with this hybrid system.

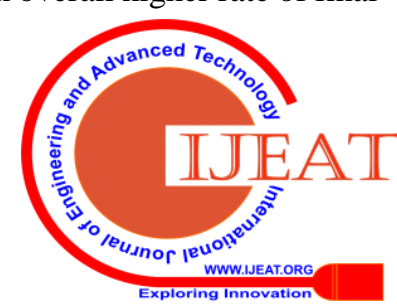




\section{Design and Implementation of Rural Electrification Framework using Photovoltaic system}
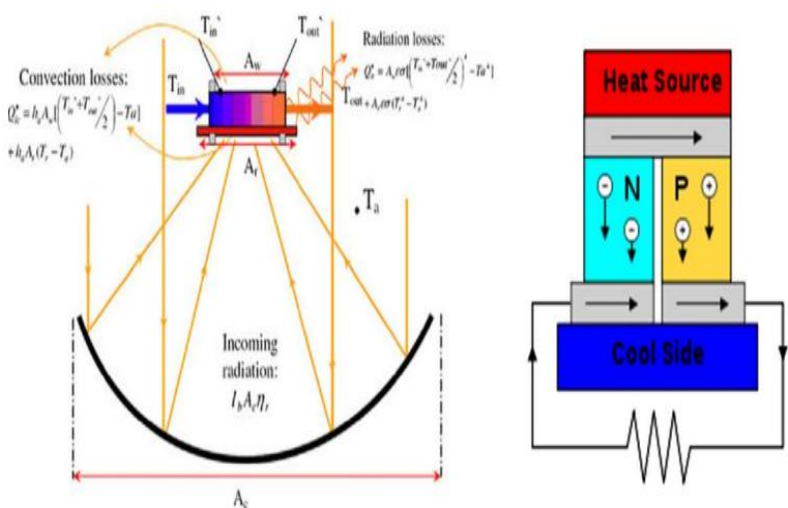

Fig. 2.1: The Working Mechanism of a Solar Thermoelectricity System

Fig.2.1 indicates the mechanism of operation of a solar thermoelectric device. Light from the sun is harvested by the concentrator and attention is accorded to irradiation within a small area. This would eventually create a temperature surge to very high and is founded on the ratio of concentration. Ultimately, the transfer of heat to cold side from the hot side occurs through thermoelectric material and generates voltage.

\section{B. Dye Sensitized Solar Cell}

A dye-sensitized solar cell which is also commonly termed as DSSC, DYSC or DSC relies on a semiconductor that has been developed between an electrolyte and photo-sensitized anode, which happens to be a photo electrochemical system. In addition, it is also frequently termed as the Gratzel cell [10]. In this system, sunlight enters the cell via a transparent cover and ultimately hits the $\mathrm{TiO} 2$ surface dye thus, exciting the dye. Thereafter, the TiO2s conduction band witnesses the entry of an electron. Later, it moves via diffusion to the clear anode located in the upper area. The mechanism is depicted in figure 2.2.
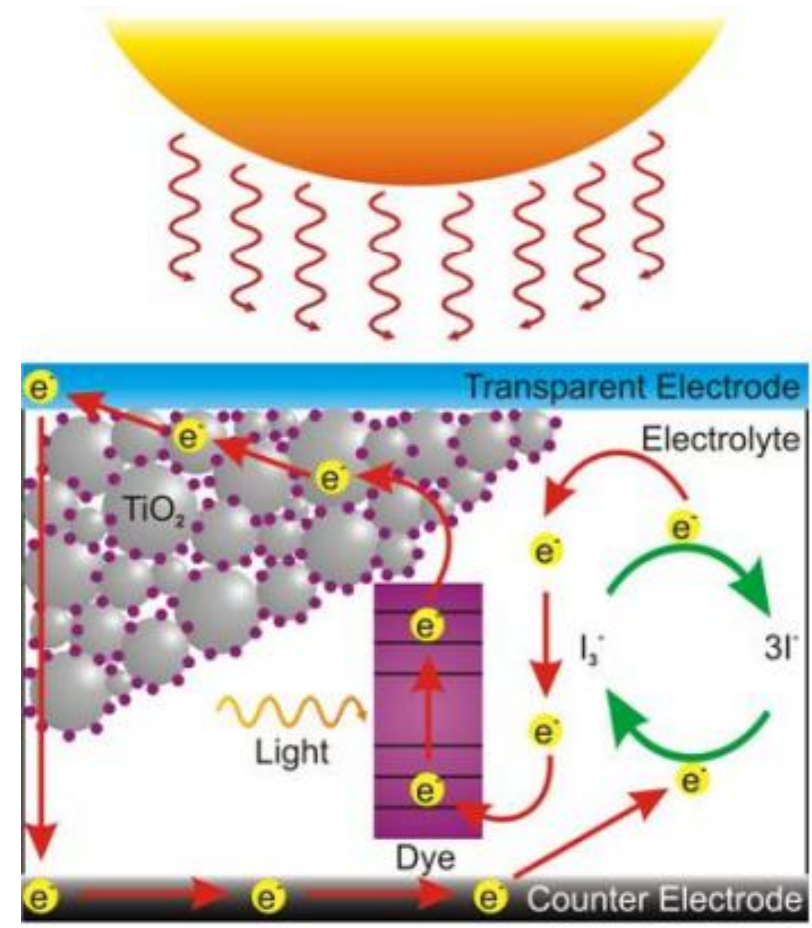

Fig. 2.2: The mechanism of DSSC

\section{Concentrated Photovoltaic (CPV)}

The concentrated photovoltaic technology utilizes optics. For instance, lenses are deployed to focus the magnanimous power of sunlight within a specific area of the photovoltaic material, in order to generate electricity. Systems that are categorized as CPV are done so on the basis of the quantum of solar concentration, computed in sun.
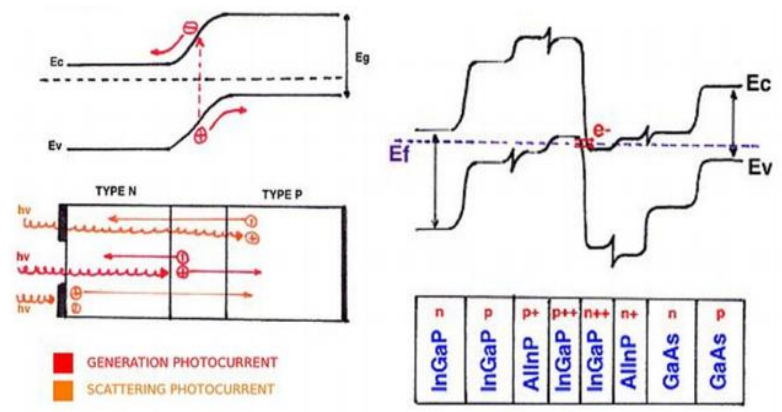

Fig.2.3: Schematic illustration of the PV effect and band structure of the tunnel junction

\section{Photovoltaic Solar Panels (PV)}

Photovoltaic as a technology is considered as an approach through which electricity is generated when solar radiation is converted into direct current, with the use of semiconductors that project the photovoltaic effect. Solar panels are utilized in the production of electricity through photovoltaic systems. These are inclusive of many solar cells comprising of photovoltaic material.

\section{E. Concentrated Solar Power (CSP)}

Lenses or mirrors are utilized within concentrated solar power techniques to focus on a large area of solar thermal energy or sunlight into a small area. When the focused light is transformed into heat, electrical power is produced which then encourages a heat engine usually from a steam turbine, which is associated with an electrical power generator [11].

\section{F. Types of PV Installations and Technology}

Kumar and Rosen [12] state that different PV installations and technologies are available and would comprise of off-grid (mainly ground or roof based installations in silos for residence and standalone operations), grid-tied centralized (major power plants), off-grid commercial (industrial and power plant installations in remote locations) and grid-tied distributed (small setups on the ground or roof). Nonetheless, for every installation, there are substantial variations in terms of requirements.

\section{G. Renewable Energy Policy in India}

Kumar and Meena [13] state that for renewable energy to be effectively adopted within any nation, it is essential to have a sound policy framework. The draft policy for renewable energy in India encompasses the need for meeting minimal energy requirements from the sector for renewable energy. It also includes provision of power of grid quality and providing energy supply for agriculture and industry within rural and urban areas in a decentralized manner. These form the wider objectives in the draft policy. It is also postulated that 10 per cent of capacity from grid power generation is supposed to be met by renewable energy and accordingly, government policies are targeting it.

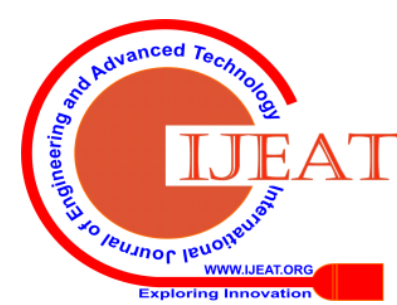




\section{H. Energy Requirements in Rural India}

The manner in which electricity is consumed within rural and urban areas largely vary. According to some estimates, it is imperative to consider a normative minimum. Minimum level of consumption within urban and rural areas if only five people exist per household, then it would be 500kWh and $250 \mathrm{kWh}$ respectively. This calculation has been arrived at assuming that within rural areas, the said quantum of energy would be consumed for two CFLs, one floor fan and mobile phone. In urban areas the power consumption would be for two mobile phones, refrigerator, computer or television. It seems to be unfair that the rural household electricity consumption does not take a television or a computer into account.

\section{Status of Solar PV in India}

Renewable hybrid system with solar PV and biomass that extends renewable power solutions was investigated by Janardhan et al.[14]. The electricity load requirement of Maulana Ganj village was calculated and the resources required to satiate this load was predicted. From the conclusion of this study, it was evident that biomass and solar hybrid systems can play a key role in rural electrification. Batteiger and Rotter [15] carried out a study related to off-grid solar products and EEE for rural societies within nations that were developing. They adopted an operational framework while assessing stocks in-use with the help of energy-access data method. A solar home system (SHS) within rural areas of Bangladesh was used for analysing and it was revealed that in-use stocks were substantially affected by accessing electricity of this kind. This was mainly due to the fact that moderate heavy SHSs were added by households within their in-use stocks wherein it was found to be low in common. As compared to standard EEE off-grid solar products were lighter and accessibility is restricted to limited products.

\section{MATERIALS AND METHODS}

The aim of the present research is to design and develop a framework with photovoltaic systems for rural electrification in India. The development of a framework does lead policy makers and practitioners to implement solar PV systems in un-electrified rural regions in India. In this regard, the following objectives are framed:

- To identify villages that are un-electrified in India and the prospects for solar PV based electrification in the select villages.

- To design solar PV systems for three different scenarios using solar PV simulation software.

- To design a framework that encompasses overall requirements in terms of cost for the implementation of solar PV systems, the suitability of individual solutions or connected grid and so on.

For the current research, the researcher has attempted to design and implement a framework for rural electrification for specific villages in India that are not electrified. The researcher intended to utilize solar photovoltaic (PV) system as the medium to enhance the status of electrification in India. For this research, the state of Madhya Pradesh in India was chosen considering the fact that it has substantial solar irradiation levels. In addition, there is dearth of electricity in several villages across districts of Katni, Umarra, Damoh and Sagar [16].

\section{RESULT AND DISCUSSION}

\section{A. Energy requirements for a small house}

For a small house, the following are the energy requirements depicted in Table 1. Daily usage of electricity is given in $\mathrm{h}$ /day and the daily energy consumption is given in Wh.

Table 1. Daily Energy requirements

\begin{tabular}{|l|l|l|l|l|}
\hline & Number & Power & $\begin{array}{l}\text { Daily use } \\
\text { (h/day) }\end{array}$ & $\begin{array}{l}\text { Daily } \\
\text { Energy } \\
\text { (Wh) }\end{array}$ \\
\hline $\begin{array}{l}\text { Tube } \\
\text { Lights }\end{array}$ & 1 & $\begin{array}{l}40 \\
\text { W/lamp }\end{array}$ & 6 & 240 \\
\hline Television & 1 & $60 \mathrm{~W} / \mathrm{TV}$ & 5 & 300 \\
\hline Fan & 1 & $80 \mathrm{~W} /$ Fan & 16 & 1280 \\
\hline Fridge & 1 & $\begin{array}{l}1.37 \\
\mathrm{kWh} / \text { day }\end{array}$ & 24 & 1368 \\
\hline
\end{tabular}

Total Daily energy $\quad=3212 \mathrm{Wh} /$ day

Total monthly energy $\quad=96.4 \mathrm{kWh} /$ month

Annual Energy Requirement $=$ Total monthly energy*12 Months

$$
=96.4 \mathrm{kWh} * 12 \rightarrow 1156.8 \mathrm{kWh}
$$

\section{B. Direct Normal Irradiance}

The annual as well as monthly average everyday total solar resource kilowatt hours per square meter for the location that has been chosen for this research is depicted through Table 2. In the conceptual sense, direct normal irradiance (DNI) happens to be the quantum of solar radiation that is received for each unit area by a surface that is always held in a perpendicular position, to the sun's rays that fall in a straight line from the sun's direction from its present position in the sky.

\section{Irradiance $=\frac{\text { Average Insolation }}{\text { Average daily bright sunshine hours }} \mathrm{kWhm}^{2}$}

\section{Monthly Global Solar Irradiation in Damoh}

On the basis of the values of irradiation that were acquired for the Damoh region as is evident from Table 2, the plot for irradiation was developed with the help of PVsyst and has been projected. From the data, it was found that the solar panel required around $4 \mathrm{~m} 2$ total area and the overall nominal power of the solar panel was found to be $0.7 \mathrm{Kw}$. In addition, on the basis of the values for irradiation, the output of energy generated by the system has been projected.

Published By:

Blue Eyes Intelligence Engineering

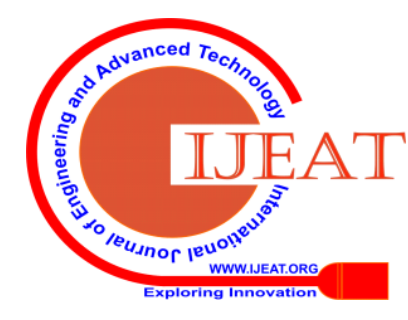




\section{Design and Implementation of Rural Electrification Framework using Photovoltaic system}

Table 2. Monthly Global solar irradiance in Damoh District

\begin{tabular}{|c|c|}
\hline Month & Solar Insolation $\mathrm{kWh} / \mathrm{m}^{2}$ \\
\hline January & 5.78 \\
\hline February & 6.84 \\
\hline March & 7.11 \\
\hline April & 6.60 \\
\hline May & 6.51 \\
\hline June & 4.42 \\
\hline July & 2.46 \\
\hline August & 2.65 \\
\hline September & 4.85 \\
\hline October & 6.45 \\
\hline November & 6.30 \\
\hline December & 5.93 \\
\hline Average & 5.48 \\
\hline
\end{tabular}

\section{Storage}

A battery is needed for a system in silo and the chosen battery was equipped with a capacity of $12.8 \mathrm{~V} 103 \mathrm{Ah}$ (Li LFP Battery module Li-ion). This battery was found to be the most appropriate considering the fact that the requirement for energy for our study was medium. In case a battery having a superior capacity would have been chosen, it would have then warranted the need for a backup generator.

\section{E. Total Investment}

The PV module that had been chosen was polycrystalline (110 Wp) which was valued at around Rs. 34 and it was being used within 16 modules, within a total area of $36.9 \mathrm{~m} 2$ (Team, 2018).

Around 26 batteries of 13V/3Ah was required (26* Rs $990=$ Rs 25740)

\section{F. Comparison}

Out of the three cases on the basis of the three objectives of design which have been evaluated through this research, the system which is connected to a grid emerged to be the one which was found to be highly efficient in terms of cost. Whereas the standalone system proved to be expensive, hence is not advisable as a PV system for individual houses. In the instance when a solar panel was connected with a charge controller, local battery was charged in times of excessive flow. It was later fed to a microgrid and can be chosen, as the costs associated with setup happens to be mildly on the higher side, as compared to the system which is connected to the grid. Nonetheless, the level of efficiency is quite high with regards to having a fairly good system of backup for individual houses and there is less scope for excessive energy to go waste. Therefore, this system is highly recommended taking into account factors related to reliability and cost.The result discussion falls under the following category. Damoh district in Madhya Pradesh, India was chosen for the current research as this region had many villages that did not have electricity. Further, the level of solar irradiation within the state of Madhya Pradesh is found to be very high. There were around 8 villages comprising of 1300 households that were devoid of electricity. Nonetheless, installing solar PV systems warranted a detailed scrutiny of diverse aspects like suitability for installing PV systems, costs and the kind of PV system which was most appropriate to be installed. Therefore, three solar PV designs were designed and developed. The first design related to linking an inverter with the solar panels and then to a microgrid. Utilizing solar PVs and its link with microgrids have found mention in researches that have been conducted in the past [17]. Several issues can be circumvented by linking a home's solar PVs to a microgrid. First and foremost, this technique is known to be viable from an economic perspective as has been mentioned by Jhunjhunwala et al. (2016), in the event that it is implemented with load shedding methods. Secondly, homes would be in a position to receive uninterrupted power if they are connected to microgrids Jhunjhunwala et al. (2016).

The objective of the second design was to implement individual solar PV solutions with no links to the microgrid. Individual systems of such kind are usually installed in nations that are developing and are believed to provide electric supply to mammoth installations like hospitals, schools etc. In addition, there is ease of maintenance and operation associated with such systems [19]. Nonetheless, to facilitate the operation of individual systems, additional components are needed by individual homes and these would include; solar charge controllers and batteries. The objective of the third design was linked with implementing a solar PV system that was linked to a micro grid where additional elements like charge controllers and charge local batter were included. This was done to facilitate uninterrupted power supply even when there was no power being received from the microgrid. This concept of solar PV installation can be categorized under self-consumption where electricity that has been generated from solar PVs, would be utilized to the maximum while minimizing consumption of electricity from the utility grid [20]. Implementing the design as mentioned in the third design objective has the potential to satisfy the energy demand. At the same time the surplus energy that will be generated would be supplied to the grid.

\section{A. Rural Electrification Framework}

On the basis of the findings from the research, it has been found that implementing solar PV systems for villages in India that do not have electricity should essentially take into account aspects like investment costs, demand for energy in future and the feasibility of implementing the type of solar PV systems. Considering the fact that this research particularly explored rural areas in India, the most important aspect would pertain to costs. Keeping in mind the objective of this research, a framework for rural electrification has been designed and developed and is indicated through the figure below. As per the figure, it can be observed that implementing solar PV systems should take into account its applicability which has been showcased for every design that has been considered within this research. Implementing design objective 2 is found to be most appropriate when solar PV systems are being designed for homes that are secluded, and located in random locations within a village.

Published By:

Blue Eyes Intelligence Engineering

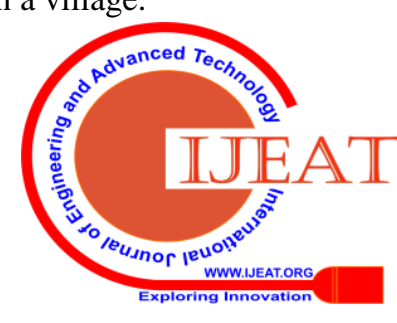


Design objective 2 is found on the premise that implementing a common grid can prove to be expensive. Moreover, in a village Dhakorwaha Ryt falling under Damoh district, Madhya Pradesh, only 9 houses existed [21] and since the number of homes were only few, installing a separate microgrid was not very feasible. Therefore, for such small numbers, design objective 2 can prove to be the most suitable.

\section{CONCLUSION}

In the current research, the significance of solar PV systems in terms of providing electricity for villages that do not have electricity in India was investigated. It was found that in parts of the nation that has superior scope to leverage the potential of solar energy. In case the village in those regions were not electrified, electricity can be provided by implementing the proposed solar PV system solution. It was found that each of the three designs which were simulated with the help of PV system were fit to be recommended for rural household electrification. Nonetheless, a major consideration with regards to implementing solar PV system would pertain to the cost of such systems. The government of India is offering subsidies that facilitate the implementation of solar PV systems. Therefore effectively using such subsidies can enhance the utility of such systems in rural areas.

\section{REFERENCES}

1. D. J. Arent, 2A. Wise, and 3R. Gelman, "The status and prospects of renewable energy for combating global warming," Energy Econ., vol. 33, no. 4, pp. 584-593, Jul. 2011.

2. C. Zou, 2Q. Zhao, 3G. Zhang, and 4B. Xiong, "Energy revolution: From a fossil energy era to a new energy era," Nat. Gas Ind. B, vol. 3, no. 1, pp. 1-11, Jan. 2016.

3. A. Chel and 2G. Kaushik, "Renewable energy technologies for sustainable development of energy efficient building," Alexandria Eng. J., vol. 57, no. 2, pp. 655-669, Jun. 2018.

4. Office of the Registrar General \& Census Commissioner, "2011 Census Data," Office of the Registrar General \& Census Commissioner, India, 2011. [Online]. Available: http://censusindia.gov.in/2011-Common/CensusData2011.html. [Accessed: 15-Dec-2018].B. Smith, "An approach to graphs of linear forms (Unpublished work style)," unpublished.

5. H. S. K. Nathan, "Solar Energy for Rural Electricity in India," Econ. Polit. Wkly., vol. 49, no. 50, pp. 60-67, 2014.

6. M. Aklin, 2P. Bayer, 3S. P. Harish, and 4J. Urpelainen, "Quantifying slum electrification in India and explaining local variation," Energy, vol. 80, pp. 203-212, Feb. 2015.

7. H. Yadav, 2V. Kumar, and 3V. Yadav, Potential of Solar Energy in India: A Review. 2015.

8. N. G. Kulkarni and 2V. B. Virulkar, "Power Electronics and Its Application to Solar Photovoltaic Systems in India," Energy Power Eng., vol. 8, no. 2, pp. 76-91, 2016.

9. H. Fan, "Power Generation from Thermoelectric Cells by Using Solar Parabolic Concentration Dish Hongnan Fan School of Aerospace , Mechanical and," RMIT University, 2011.

10. F.-T. Kong, 2S.-Y. Dai, and 3K.-J. Wang, "Review of Recent Progress in Dye-Sensitized Solar Cells," Adv. Optoelectron., vol. 2007, pp. 1-13, 2007.

11. F.-T. Kong, 2S.-Y. Dai, and 3K.-J. Wang, "Review of Recent Progress in Dye-Sensitized Solar Cells," Adv. Optoelectron., vol. 2007, pp. 1-13, 2007.

12. R. Kumar and 2M. A. Rosen, "A critical review of photovoltaic-thermal solar collectors for air heating," Appl. Energy, vol. 88, no. 11, pp. 3603-3614, Nov. 2011.

13. S. Kumar and 2R. L. Meena, "Renewable Energy Sources - Policies in India,” Int. J. Appl. Environ. Sci., vol. 12, no. 2, pp. 293-297, 2017.

14. K. Janardhan, 2T. Srivastava, 3G. Satpathy, and 4K. Sudhakar, "Hybrid solar PV and biomass system for rural electrification,” Int. J. ChemTech Res., vol. 5, no. 2, pp. 802-810, 2013.

15. A. Batteiger and 2V. Rotter, "Material Implications of Rural Electrification-A Methodological Framework to Assess In-Use Stocks of Off-Grid Solar Products and EEE in Rural Households in Bangladesh," Recycling, vol. 3, no. 1, p. 7, Feb. 2018.

16. Garv, "GARV," $2019 . \quad$ [Online]. Available: http://garv.gov.in/dashboard. [Accessed: 07-Feb-2019].

17. A. S. O. Ogunjuyigbe, 2T. R. Ayodele, and 3C. G. Monyei, "An intelligent load manager for PV powered off-grid residential houses," Energy Sustain. Dev., vol. 26, pp. 34-42, Jun. 2015.

18. A. Jhunjhunwala, 2A. Lolla, and 3P. Kaur, "Solar-dc Microgrid for Indian Homes: A Transforming Power Scenario," IEEE Electrif. Mag., vol. 4, no. 2, pp. 10-19, Jun. 2016.

19. Alliance for Rural Electrification, "Rural El ect rification with Re newable Energy: Technologies, quality standards and business models," Alliance for Rural Electrification, 2011.

20. C. Sarasa-Maestro, 2R. Dufo-López, and 3J. Bernal-Agustín, “Analysis of Photovoltaic Self-Consumption Systems,” Energies, vol. 9, no. 9, p. 681, Aug. 2016

21. Tendukheda, "Indian Village Directory," 2018.

\section{AUTHORS PROFILE}

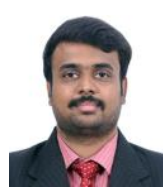

N.Rishikesh received B.E Degree in Electrical and Electronics Engineering from Raja Lakshmi Engineering College, Chennai in 2015, M.Sc Degree in Electrical Power Engineering with Advanced Practice from the University of Northumbria, U.K in 2018.Currently he is an assistant professor of Electrical and Electronics Engineering at Bannari Amman Institute of Technology, Erode. His fields of interest include Renewable energy and Power engineering.

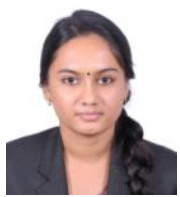

N.P.Gopika received B.E Degree in Electrical and Electronics Engineering from CUSAT university in 2016 M.E Degree in Power and Energy systems from amrita school of engineeringi in 2019.Currently she is an Assistant professor of Electrical and Electronics Engineering at Bannari Amman Institute of Technology, Erode. Her fields of interest include smart grid and power quality.

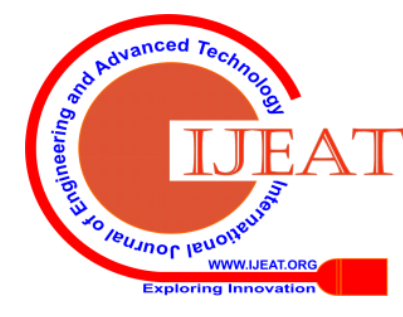

